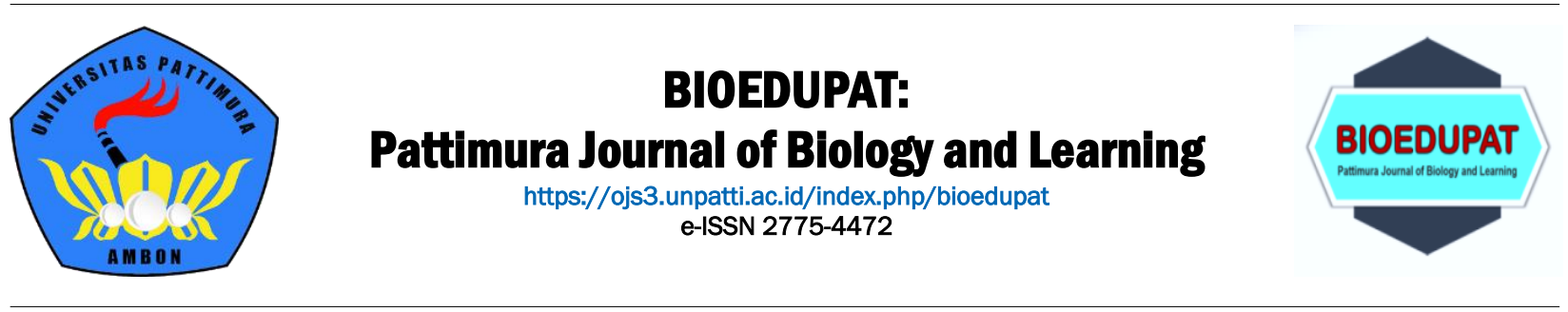

Research Article

\title{
PjBL-HOTS learning model: Its application and effect on cognitive learning outcomes, critical thinking, and social attitudes
}

\author{
Aminah Launuru1,, Dominggus Rumahlatu², Muhammad Nur Matdoan² \\ ${ }^{1}$ SMA Negeri 6 Leihitu, Jl. Nanihaha, Hila 97582, Indonesia \\ 2 Study Program of Biology Education, Faculty of Teacher Training and Education, Pattimura University, \\ JI. Ir. M. Putuhena, Ambon 97233, Indonesia \\ * corresponding author: aminalaunuru@gmail.com
}

Received: 17 February 2021

Revised: 12 March 2021

Accepted: 21 April 2021

\begin{abstract}
Learning in the digital era 4.0 brings changes for teachers and students. Teachers must prepare innovative digital-based learning to improve students' higher-order thinking skills. This study aims to analyze the effect of the application of the PjBL-HOTS learning model on cognitive learning outcomes, critical thinking, and social attitudes. This type of research is a quasi-experimental research design, which uses a pretest-posttest nonequivalent group design. The study used two classes, namely class X1 as the experimental class while class $\mathrm{X} 2$ as the control class. The research instrument is in the form of essay questions to assess students 'cognitive learning outcomes and students critical thinking. Meanwhile, a questionnaire is used to assess students' social attitudes. The data analysis used descriptive and inferential analysis techniques. The inferential analysis used ANCOVA and ANOVA analysis with a significant level of $a=0.05$. The results showed that there was an effect of the PjBL-HOTS learning model in improving students' cognitive learning outcomes, critical thinking, and social attitudes. This is because the ability to think critically is always empowered by the teacher at every stage of PjBL.
\end{abstract}

Keywords: PjBL-HOTS, cognitive, critical thinking, social attitudes

To cite this article:

Launuru, A., Rumahlatu, D., \& Matdoan, M. N. (2021). PjBL-HOTS learning model: Its application and effect on cognitive learning outcomes, critical thinking and social attitudes. Bioedupat: Pattimura Journal of Biology and Learning, Vol 1(1), 1-10. DOl: https://doi.org/10.30598/bioedupatv1i1pp1-10

\section{INTRODUCTION}

Higher Order Thinking Skills (HOTS) is one of the higher-order thinking skills that need to be developed in the current era of the Industrial Revolution (RI) 4.0. According to Heong et al. (2011), through higher-order thinking, students will use thinking widely. This will make students challenged to find something new. Kusuma et al. (2017) added that HOTS requires students to be able to apply the new information they get, and then manipulate the information to find new answers. The new answers are meant to be answers that are processed through creative and innovative thoughts from students.

According to Dinni (2018), HOTS consists of the ability to connect, manipulate, and change the knowledge and experience that is already owned critically and creatively in determining decisions to solve problems in new situations. 
Meanwhile, according to Brookhart (2010), the HOTS category includes analytical skills, evaluation, creation, logical reasoning, critical thinking, problem-solving, creativity, and creative thinking.

Several researchers have analyzed HOTS abilities in high school students. Samosir et al. (2019) conducted a study to analyze HOTS on questions given by the teacher. Research done by Istiyono et al. (2014) is also oriented towards HOTS analysis on student academic ability tests. The research shows that students' HOTS are assessed in the form of learning evaluation. However, there is no HOTS integration in biology learning. Research conducted by Widodo \& Kadarwati (2013) shows that Higher Order Thinking and Problem Based Instruction learning models can be integrated into HOT-PBI and can improve student character, cognitive, and higher-order thinking skills. Tajudin et al. (2016) also emphasized that teachers can use the HOTS learning principle by diversifying it with several learning models.

Therefore, the HOTS of these students can also be integrated into PjBL learning. The Project-Based Learning $(\mathrm{PjBL})$ learning model is an innovative learning model that emphasizes the investigation process by students and produces a scientific product. Research by Rumahlatu \& Sangur (2019) has shown that the application of PjBL compared to conventional learning models has been able to empower metacognitive abilities and student learning outcomes. By using the right learning model, it is hoped that Indonesia's young generation will be ready and confident to face the various challenges and changes that have occurred due to the influence of the 4.0 industrial revolution.

High school biology teachers in Ambon city have implemented many innovative cooperative learning models. These learning models are STAD, PBL, PjBL, NHT, GI, and many other models. However, the application of learning models and HOTS integration in learning to improve students' higher-order thinking skills has not been done by high school biology teachers. Research conducted by Leiwakabessy et al. (2018) show that HOTS-based evaluations conducted by biology teachers at several schools such as SMA 1 Ambon, SMA 3 Ambon, SMA 4 Ambon, SMA Siwalima Ambon, and SMA Xaverius Ambon have been able to compile HOTS questions of $93.75 \%$. This means that high school biology teachers have been able to evaluate HOTS, but the application of HOTS in learning has not been done. For HOTS evaluation to be effective and efficient to empower students, teachers need to design HOTS-based learning, so that the learning and evaluation process becomes one unit. Therefore, this research is important to do to examine the application of the integration of the PjBL-HOTS learning model for empowering cognitive learning outcomes, students 'critical thinking abilities, and students' social attitudes at SMA 6 Leihitu.

\section{METHODS}

\section{Research design}

This research is quasi-experimental research, which uses a pretest-posttest nonequivalent group design. The independent variables of this study are the conventional learning model (STAD) and the PjBL-HOTS learning model, while the dependent variable is the cognitive learning outcomes, critical thinking skills, and students' social attitudes. The quasi-experimental research design is shown in Table 1, as follows.

Tabel 1. Research design

\begin{tabular}{lll}
\hline Y1 & $X 1$ & $Y 2$ \\
\hline$Y 1$ & $X 2$ & $Y 2$ \\
\hline Note: & & \\
$Y 1$ & $:$ Pretest & \\
$Y 2$ & $:$ Posttest & \\
$X 1$ & $:$ PjBL-HOTS Learning Model \\
$X 2$ & $:$ STAD Model &
\end{tabular}

\section{Sample of research}

The populations used in this study were all students of class XI SMA 6 Leihitu. The research sample consisted of two classes, namely $\mathrm{X} 1$ as the experimental class which was taught using the PjBL-HOTS learning model, while class $\mathrm{X} 2$ was the control class which was taught using the conventional model (STAD).

\section{Instruments and procedures}

The instruments developed in this study were test questions and scoring rubrics. The items were prepared to refer to the competency standards in accordance with the provisions of the National Education Standards Agency (NESA), Indonesia. The items arranged are essay items that are used to measure students' critical thinking skills and cognitive 
learning outcomes. The scoring rubric is a list of criteria to measure cognitive learning outcomes and critical thinking. A questionnaire is provided for students to assess their respective social attitude skills.

The implementation of learning in each class is carried out almost simultaneously and uses different learning tools, but the assessment of the dependent variable (cognitive learning outcomes, students 'critical thinking, and students' social attitudes) remains the same. The method of data collection and grouping is as follows.

1. The pretest is given to each class before the application of the learning model. The pretest results of cognitive learning outcomes and critical thinking were used as covariates in the ANCOVA statistical analysis.

2. The learning implementation in the experimental class uses the PjBL-HOTS learning stage: (a) Planning; critical in analyzing topics that become phenomena in society, think critically of relevant information to discuss the topic, doing the division of tasks in groups; (b) Creating; think critically in preparing the project stage, think critically in project implementation, create a product, think critically in preparing project reports; (c) Presenting; think critically in doing a presentation. While the control class uses the STAD learning stage which is a learning model that is always used by teachers while learning the concept of the human body defense system. The steps are as follows (a) Learning preparation: students are divided into 4-6 groups, students are grouped into heterogeneous groups based on academic ability, gender, race and ethnicity; (b) Material presentation: teacher explains the learning objectives, motivates students to work together in their group, the teacher presents the material of the human body defense system; (c) Group study activities: teacher distributes worksheets for students, the teacher guides students to discuss together; (d) Examination of group results:teacher guides students to make group presentations and asses their presentation; (e) Students work on individual test questions (Individual tests are carried out to determine the extent to which learning success has been achieved, individual tests are held on the material that has been discussed); (f) Group awards: teacher gives awards to the group that gets the highest score for the presentation phase and individual tests

3. During the learning process, students assess their social attitudes.

4. Posttest is given after the application of the learning model. The results of the posttest were used to measure students' cognitive learning outcomes and critical thinking.

\section{Data analysis}

The research data were analyzed using descriptive and inferential statistics. Descriptive statistics are used to determine the data group and the distribution of data on cognitive learning outcomes, critical thinking, and social attitudes at intervals and data classes. Inferential statistics begins with an analysis of data homogeneity and normality. The homogeneity test used the Levene test and the normality test used the Kolmogorov-Smirnov test. Furthermore, two-way covariance analysis (ANCOVA) was used to analyze: (1) the effect of the application of learning models on student cognitive learning outcomes. (2) the effect of the application of the learning model on students' critical thinking skills. While the analysis of variance (ANOVA) was used to analyze the effect of the application of the learning model on students' social attitudes. Furthermore, if there is a difference, a further test of the post hoc least significant difference (LSD) is carried out to determine the average difference which is statistically significant. Data analysis was performed using the SPSS 18.0 program.

\section{RESULTS AND DISCUSSION}

\section{Cognitive learning outcomes}

Descriptions of students' cognitive learning outcomes in the experimental and control classes are described in Table 2.

Table 2. Cognitive learning outcomes in the control and experimental class

\begin{tabular}{cccccccccccc}
\hline \multicolumn{4}{c}{ Control Class } & \multicolumn{3}{c}{ Posttest } & \multicolumn{3}{c}{ Pretest } & \multicolumn{3}{c}{ Posttest } \\
\hline \multicolumn{3}{c}{ Pretest } & \multicolumn{3}{c}{ Experiment Class } \\
\hline Interval & F & RF (\%) & Interval & F & RF (\%) & Interval & F & RF (\%) & Interval & F & RF (\%) \\
\hline $27-30$ & 8 & 30.77 & $66-70$ & 12 & 46.15 & $27-30$ & 9 & 34.62 & $57-63$ & 1 & 3.85 \\
$31-34$ & 9 & 34.62 & $71-74$ & 2 & 7.69 & $31-34$ & 8 & 30.77 & $64-70$ & 5 & 19.23 \\
$35-38$ & 5 & 19.23 & $75-78$ & 0 & 0 & $35-38$ & 5 & 19.23 & $71-77$ & 2 & 7.69 \\
\hline
\end{tabular}




\begin{tabular}{cccccccccccc}
\hline $39-42$ & 3 & 11.54 & $79-82$ & 10 & 38.46 & $39-42$ & 3 & 11.54 & $78-84$ & 6 & 23.08 \\
$43-46$ & 0 & 0 & $83-86$ & 0 & 0 & $43-46$ & 0 & 0 & $85-91$ & 9 & 34.62 \\
$47-50$ & 1 & 3.85 & $87-90$ & 2 & 7.69 & $47-50$ & 1 & 3.85 & $92-98$ & 3 & 11.54 \\
Total & 26 & 100 & Total & 26 & 100 & Total & 26 & 100 & Total & 26 & 100 \\
\hline
\end{tabular}

Description: F: frequency; RF: relative frequency

The distribution of scores on the initial test of $100 \%$ is in the range of $27-50$ scores for the control and experimental classes, this shows that students have a low level of mastery of the body's defense system material. Whereas in the final test $100 \%$ of students had improved scores in both the control and experimental classes. This means that there is an increase in the value between before and after students are taught using conventional learning models at SMA 6 Leihitu. Research by Narahaubun et al. (2020) also showed that before the application of the learning model, cognitive learning outcomes that revealed students' conceptual understanding of material were very low compared to after learning in both the experimental class and the control class. After going through the learning process, students' understanding of the concept of the human body's defense system has increased. Rumahlatu et al. (2020) also explained that cognitive learning outcomes are related to students' understanding of a concept, so it is called a conceptual understanding that can be formed through the learning process.

\section{Critical thinking}

Students' critical thinking in the experimental and control classes is described in Table 3 below.

Table 3. Results of the experimental class critical thinking

\begin{tabular}{|c|c|c|c|c|c|c|c|c|c|c|c|}
\hline \multicolumn{6}{|c|}{ Control Class } & \multicolumn{6}{|c|}{ Experiment Class } \\
\hline \multicolumn{3}{|c|}{ Pretest } & \multicolumn{3}{|c|}{ Posttest } & \multicolumn{3}{|c|}{ Pretest } & \multicolumn{3}{|c|}{ Posttest } \\
\hline Interval & $\mathbf{F}$ & $\mathrm{RF}(\%)$ & Interval & $\mathbf{F}$ & RF (\%) & Interval & $F$ & RF (\%) & Interval & $F$ & RF (\%) \\
\hline $6-8$ & 10 & 38.46 & $13-15$ & 1 & 3.85 & $6-8$ & 7 & 26.92 & $13-15$ & 5 & 19.23 \\
\hline $9-11$ & 15 & 57.69 & $16-18$ & 24 & 92.31 & $9-11$ & 14 & 53.85 & $16-18$ & 8 & 30.77 \\
\hline \multirow[t]{2}{*}{$12-14$} & 1 & 3.85 & $19-21$ & 1 & 3.85 & $12-14$ & 5 & 19.23 & $19-21$ & 8 & 30.77 \\
\hline & & & & & & & & & $22-24$ & 5 & 19.23 \\
\hline Total & 26 & 100 & Total & 26 & 100 & Total & 26 & 100 & Total & 26 & 100 \\
\hline
\end{tabular}

Description: F: frequency; RF: relative frequency

The distribution of scores on the initial critical thinking test was 100\% in the range of 6-14 in both the control and experimental classes (Table 3). Meanwhile, in the final test, $100 \%$ of students 'critical thinking has succeeded in improving students' critical thinking through PjBL-HOTS learning. This means that there is an increase in the value between before and after students are taught using the PjBL-HOTS and STAD learning models at SMA Negeri 6 Leihitu. However, PjBL-HOTS learning has a higher increase compared to learning using STAD, this is shown by the percentage increase in the experimental class by $50 \%$ compared to the control class using STAD learning. According to Çimer et al. (2013), the ability to think critically is a culture that is empowered continuously in learning. The same thing was conveyed by Setiawati \& Corebima (2017) the ability to think critically does not appear automatically but through guided training and practice in learning until students can use it. Through the learning stages, students' critical thinking skills can be empowered in learning.

\section{Social attitude}

The social attitudes of students in the experimental and control classes are described in Table 4 below.

Table 4. Social attitudes in the experimental and control classes

\begin{tabular}{cccccc}
\hline & \multicolumn{2}{c}{ Control Class } & \multicolumn{2}{c}{ Experiment Class } \\
\hline Interval & Frequency & Relative Frequency (\%) & Interval & Frequency & Relative Frequency (\%) \\
\hline $31-34$ & 1 & 3.85 & $36-38$ & 3 & 11.54 \\
$35-38$ & 0 & 0 & $39-41$ & 6 & 23.08 \\
\hline
\end{tabular}




\begin{tabular}{cccccc}
\hline $39-42$ & 8 & 30.77 & $42-44$ & 13 & 50 \\
$43-46$ & 11 & 42.31 & $45-47$ & 4 & 15.38 \\
$47-50$ & 6 & 23.08 & & & \\
Total & 26 & 100 & Total & 26 & 100 \\
\hline
\end{tabular}

The distribution of the value of the students' social attitudes is $100 \%$ in the range of values $31-50$. This means that students of SMA Negeri 6 Leihitu can show social attitudes in the learning process in both the experimental class and the control class. Social attitude is an assessment of students' social abilities during the learning process. Descriptive analysis shows that social attitudes in students can be developed in the experimental class and the control class.

The effect of PjBL_HOTS model application on cognitive learning outcomes, critical thinking and social attitudes

\section{Prerequisite test}

Prior to data analysis and hypothesis testing, the normality and homogeneity of the data were first tested. The data normality test used the One Sample Kolmogorov-Smirnov Test statistical test, and the homogeneity test of the data used the Leven's Test of Quality of Error Variances (Table 5).

Table 5. Prerequisite test

\begin{tabular}{lcccccc}
\hline \multicolumn{1}{c}{ Variable } & Score & Significant & Level of Trust & Score & Significant & Level of Trust \\
\hline Cognitive learning & 3.381 & .061 & $\mathrm{a}=0.05$ & .434 & .434 & $\mathrm{a}=0.05$ \\
result & & & & & & \\
Critical thinking & 2.156 & .100 & & .593 & .594 & \\
Social attitude & 1.918 & .172 & & .881 & .533 & \\
\hline
\end{tabular}

The significant value of each tested variable is greater than $a=0.05$. This means that the variable data come from a homogeneous population and is normally distributed.

\section{Hypothesis testing}

The results of hypothesis testing are used to determine the effect of the independent variables on the dependent variable. The dependent variable data shows a normal and homogeneous distribution so that it is feasible to be tested using statistical tests. ANCOVA calculation results on student cognitive learning outcomes are shown in Table 6, while further tests are shown in Table 7.

Table 6. ANCOVA cognitive learning outcomes

\begin{tabular}{|c|c|c|c|c|c|}
\hline Source & Type III sum of squares & df & Mean square & $F$ & Sig. \\
\hline Corrected model & $771.608^{a}$ & 2 & 385.804 & 4.919 & .011 \\
\hline Intercept & 7615.590 & 1 & 7615.590 & 97.101 & .000 \\
\hline Pretest & 10.051 & 1 & 10.051 & .128 & .722 \\
\hline Learning model & 761.558 & 1 & 761.558 & 9.710 & .003 \\
\hline Error & 3843.065 & 49 & 78.430 & & \\
\hline Total & 311231.000 & 52 & & & \\
\hline Corrected total & 4614.673 & 51 & & & \\
\hline
\end{tabular}

Table 7. Further tests of students' cognitive abilities LSD

\begin{tabular}{lcc}
\hline \multicolumn{1}{c}{ Learning Model } & Average & LSD Notation \\
\hline Experiment & 80.6154 & $\mathrm{a}$ \\
Control & 72.9615 & $\mathrm{~b}$ \\
\hline
\end{tabular}


The independent variable of the learning model is significant at $0.003<a=0.05$. Based on these results, there is an effect of the learning model on student cognitive learning outcomes (Table 6). The difference in notation between the experimental class and the control class (Table 7). This proves that students who are taught using the PjBLHOTS learning model have better cognitive learning outcomes than students taught using conventional learning models. Research by Susilowati et al. (2013) shows that project-based learning affects student learning outcomes in the human digestive system material compared to conventional learning. After students complete their projects, students understand the content of the human body defense system material which is more in-depth so that students can better apply their knowledge in solving problems in real life. According to Insyasiska et al. (2015) in project-based learning, students experience the project as a whole themselves, starting from selecting topics, deciding on approaches, conducting experiments, drawing conclusions, and communicating the results of the project. Several studies on the PjBL learning model show that PjBL is constructivist based to shape student concepts. In this study, $\mathrm{PjBL}$ is combined with HOTS to become PjBL-HOTS which still reflects PjBL's constructivist to form student concepts independently.

The PjBL-HOTS stage contains a combination of project stages with critical thinking skills. At the critical stage in analyzing the topic, students are provided with the experience of finding information and reading this information to compile a project implementation plan, to project reports. At this stage students can develop cognitively by reading, taking notes, and detailing the stages of the project and report implementation. Klein et al. (2009) explain that projectbased learning can empower students to pursue their knowledge. Anazifa \& Hadi (2016) project-based learning also improves students' learning abilities. The two opinions above indicate that PjBL learning can empower students to understand the material they are learning independently. Meanwhile, this learning is based on the PjBL-HOTS integration which is also able to improve students' cognitive learning outcomes because there are already critical thinking stages in the project learning stage.

The next stage is critical thinking on relevant information to be used to solve problems/phenomena, division of tasks into groups, compiling work stages, implementation to product manufacturing. In each stage of project learning, critical thinking skills are continuously trained so that students become accustomed to them. According to Husnah (2017), how to improve critical thinking skills is to read critically, develop observation skills (observe), increase curiosity, and discussion. Students can practice critical thinking during reading to find information for the group division process, the preparation of project stages, and project implementation. Reading in this process is not just reading material about the body's immune system in general but reading critically, meaning that after reading students get results from reading, namely tasks to be carried out by groups, project stages for project implementation in the immune system. The same thing was also conveyed by Christina \& Kristin (2017) that critical thinking is the ability to obtain information for solving a problem by finding this information from various sources. Walfajri \& Harjono (2014) added that critical thinking is a person's ability to make decisions, analyze problems and overcome the problems they face. Therefore, critical thinking skills are very important to use in project learning (PjBL) to improve students' cognitive abilities. Huda \& Rahman (2020) explain that students have a good cognitive way of thinking that is influenced by critical thinking habits so that it can also affect student learning achievement. Ramdani and Badriah's (2018) research shows that there is a positive correlation between critical thinking and student learning outcomes because there is the suitability of stages in the learning model that focuses on authentic problems so that it can accommodate critical thinking and cognitive learning outcomes.

Based on this opinion, HOTS's ability to think critically in combination with the PjBL learning stages can affect cognitive learning outcomes compared to the STAD learning model commonly used by teachers. Various studies have shown that STAD can improve student cognitive learning outcomes. Hasan et al. (2016) show that STAD can improve cognitive learning outcomes in its two cycles of application. The descriptive analysis also shows that STAD can improve student learning outcomes before and after the application of the learning model. However, further tests showed a significant difference between the STAD model and the PJBL-HOTS combination in improving cognitive learning outcomes for students at SMA N 6 Leihitu.

In addition to the contribution of critical thinking in the PjBL learning stages in influencing student learning outcomes, the next analysis is an analysis of the PjBL-HOTS combination in influencing critical thinking. The results of the ANCOVA calculation on students' critical thinking skills are shown in Table 8, while the LSD advanced test is shown in Table 9. 
Table 8. ANCOVA students' critical thinking skills

\begin{tabular}{|c|c|c|c|c|c|}
\hline Source & Type III sum of squares & df & Mean square & $F$ & Sig. \\
\hline Corrected model & $46.549 \mathrm{a}$ & 2 & 23.274 & 4.667 & .014 \\
\hline Intercept & 278.075 & 1 & 278.075 & 55.757 & .000 \\
\hline Critical early & 15.779 & 1 & 15.779 & 3.164 & .081 \\
\hline Learning model & 21.781 & 1 & 21.781 & 4.367 & .042 \\
\hline Error & 244.374 & 49 & 4.987 & & \\
\hline Total & 16146.000 & 52 & & & \\
\hline Corrected total & 290.923 & 51 & & & \\
\hline
\end{tabular}

Table 9. LSD further test of students' critical thinking skills

\begin{tabular}{lccc}
\hline \multicolumn{1}{c}{ Learning Model } & Average & & LSD Notation \\
\hline Experiment & 18.2308 & $\mathrm{a}$ & \\
Control & 16.6923 & & $\mathrm{~b}$ \\
\hline
\end{tabular}

Inferential analysis using the ANCOVA test shows that there is an effect of the learning model on students' critical thinking $0.042<a 0.05$ (Table 8). The LSD advanced test showed that the difference in notation between the experimental class and the control class so that the PJBL-HOTS learning model applied to the experimental class was able to improve students' higher-order thinking compared to the conventional model (STAD) in the control class (Table 9). The results showed that the PjBL-HOTS learning model is a learning model that can improve students' critical thinking skills. The use of PjBL is one effective way to train students' HOTS skills (Sambite et al., 2019). HOTS is a thought process that not only memorizes but also involves deep understanding and critical analysis thinking processes (Lukitasari et al., 2018). This constructivist-based PjBL learning model is very suitable to be used to improve HOTS, especially students' critical thinking. According to Stephani (2016), critical thinking will occur when students are allowed to analyze various information then make a decision and put the decision into practice. Through critical thinking, students can identify problems, seek information, and find solutions to these problems are stages to develop critical thinking (Putri et al., 2018).

In PjBL-HOTS learning, the series of PjBL stages are always integrated with critical thinking components. Therefore, each stage that is integrated with HOTS can improve students' critical thinking skills, compared to the STAD learning model that has been used by teachers in teaching the concept of the human body defense system. STAD is a cooperative learning model that focuses on group discussion activities, after which a test is conducted to check understanding at the end of the lesson. However, PjBL learning integrates HOTS in every lesson to improve critical thinking skills. Several studies have shown that PjBL can increase students' HOTS. According to Fitriani et al. (2015), there are differences in the ability to think critically in the control class and the experimental class because the stages of the learning model support the development of this critical thinking ability. Therefore, HOTS integration at the PjBL stage can also improve students' critical abilities. The same results were also conveyed by Wahid \& Karimah's (2018) study of the Creative Problem Solving (CPS) learning model which is integrated with HOTS which can empower students to increase the ability of students to think highly. The results of ANOVA calculations on students' social attitudes are shown in Table 10 below.

Table 10. ANOVA of the ability of social attitudes

\begin{tabular}{lccccc}
\hline & Sum of Squares & df & Mean Square & F & Sig. \\
\hline Between groups & 27.769 & 1 & 27.769 & 2.193 & .145 \\
Within groups & 633.000 & 50 & 12.660 & & \\
Total & 660.769 & 51 & & & \\
\hline
\end{tabular}

Inferential analysis using the ANOVA test shows that there is no influence of the learning model on students' social attitudes (Table 10). Social attitude is one of the important aspects that need to be presented in the learning process, especially Biology-Science. PJBL-HOTS learning and STAD (conventional) learning are also able to 
empower students' social attitudes because students can interact with other students, as well as interact with teachers. According to Gusviani (2016), social attitudes can be raised in core activities through exploration by the teacher, it can also be raised in the final activity, namely by providing advice or motivation so that students can form individuals who have good social attitudes as provisions for life in society.

The PjBL-HOTS learning stage emphasizes interaction with groups for project planning, implementation, and presentation. According to Astalini et al. (2018), social attitudes in science learning imply that students can control themselves to achieve learning goals through understanding, experimenting, being active, and liking science learning.

The same thing was conveyed by Sanjiwana et al. (2015) so that the students 'social attitudes that are formed do not deviate from the expected aspects of social attitudes, it is the teacher's task to monitor students' social attitudes according to the learning stages. At this stage, students plan the division of tasks in groups, implement projects, make products and present them in groups to increase student cooperation. Student cooperation attitudes must be honed from childhood so that students can socialize with their friends, respect friends' opinions, and work will feel lighter when done together (Listiani \& Purwanto, 2018).

According to Primandari et al. (2019) social attitudes in the form of responsibility, discipline, honesty, courtesy, group work can be trained in every lesson because students are more relaxed because it is done with peers. The PjBL-HOTS learning stages also empower responsibility, honesty and discipline, and are polite to group mates and teachers. Sukerta et al. (2014) reported that student activeness in discussion was supported by student social interaction during the learning process. Therefore, social attitudes are one of the psychological aspects of students that are very important to be nurtured and developed.

\section{CONCLUSION}

The PjBL-HOTS learning model affects students 'cognitive learning outcomes, critical thinking, and students' social attitudes. This is because the critical thinking stage is always empowered in the PjBL learning stage starting from project planning, implementation, and product presentation. Empowerment of critical thinking can affect the mastery of student cognitive learning outcomes in studying the immune system.

\section{REFERENCES}

Anazifa, R., \& Hadi, R. (2016). Environmental education through project-based learning (Project-Based Learning) in biology learning. Proceedings of the Symbion of the Biology Education Study Program, FKIP, Ahmad Dahlan University, 453-462.

Astalini, Kurniawan, D., \& Putri, A. (2018). Identification of the attitude of the social implications of science, interest in increasing science learning time, and interest in a career in science for junior high school students in Muaro Jambi Regency. Tarbiyah Journal: Scientific Journal of Education, 7(2), 93-108.

Brookhart, SM (2010). How to assess higher-order thinking skills in your classroom. Alexandria, Virginia USA.

Christina L. V ., \& Kristin, F. (2017). The effectiveness of the group investigation (G I ) type of learning model and cooperative integrated reading and composition $(\mathrm{CIRC})$ in increasing the creativity of critical thinking and social studies learning outcomes for grade 4 students. Scholaria: Journal of Education and Culture, 6 (3), 217-230.

Çimer, A., Timuçin, M., \& Kokoç, M. (2013). Critical thinking level of biology classroom survey: Ctlobics. The Online Journal of New Horizons in Education, 3(1), 15-24.

Dinni, H. N. (2018). HOTS (High Order Thinking Skills) and its relation to mathematical literacy skills. Prism 1: Proceedings of the National Mathematics Seminar, 170-176.

Fitriani, A., Indrowati, M., \& Karyanto, P. (2015). Students' critical thinking skills in biology learning through the application of accelerated learning for class X SMA Negeri Karangpan and Karanganyar. Journal of Biological Education, 7(2), 56-67.

Gusviani, E. (2016). Analysis of the emergence of spiritual attitudes and social attitudes in science learning activities for grade IV SD using KTSP and the 2013 curriculum. Eduhumaniora, 7(2), 1-10.

Heong, Y. M, Othman, W., Yunos, J. B. M., Kiong, T., Hassan, R., \& Mohamad, MM (2011). The level of Marzano higher-order thinking skills among technical education students. International Journal of Social Science and Humanity, 1(2), 121-125.

Huda, M., \& Rahman, L. (2020). The relationship between critical thinking skills and learning outcomes of elementary school students. Journal of Character Education: Journal of Child and Character Education, 2(2), 42-47.

Husnah, M. (2017). The relationship between the level of critical thinking on student physics learning outcomes by applying the problem-based learning model. Journal of Physics and Science Learning, 1(2), 1-12. 
Insyasiska, D., Zubaidah, S., \& Susilo, H. (2015). The effect of project-based learning on learning motivation, creativity, critical thinking skills, and cognitive abilities of students in biology learning. Journal of Biological Education, 7(1), 9-21.

Istiyono, E., Mardapi, D., \& Suparno, S. (2014). Development of high-level physics thinking skills test (PysTHOTS) of high school students. Journal of Educational Research and Evaluation, 18(1), 2-5.

Klein, J., Taveras, S., King, SH, Commitante, A., Bey, LC., \& Stripling, B. (2009). A Guide To project-based learning in middle schools: Inspiring students to engage in deep and active learning. NYC Department of Education.

Kusuma, M., Rosidin, U., Abdurrahman., \& Suyatna, A. (2017). The Development of higher-order thinking skill (HOTS) assessment instrument in physics study. Journal of Research \& Method in Education, 7(1), 26-32.

Leiwakabessy, F., Hetharia, M., \& Manuputty, R. (2018). Development of biological teacher capabilities in the development of test instruments based on high order thinking skills (HOTS) In high school in Ambon city that have applied 2013 Curriculum. Proceeding Book of The 3rd International Seminar on Education November 07th, $2,76-86$.

Listiani, S., \& Purwanto, A. (2018). The application of a project-based learning model using used goods to improve students' scientific attitudes. Proceedings of the Seminar and National Discussion on Basic Education, 24-29.

Lukitasari, M., Handhika, J., \& Murtafiah, W. (2018). Higher-order thinking skills: Using e-portfolio in project-based learning. In Journal of Physics: Conference, 983(12047), 1-7.

Narahaubun, S. S, Rehena, J. F., \& Rumahlatu, D. (2020). Empowering students' critical thinking skills, information literacy, and cognitive learning outcomes through the RBL-TPS model. Indonesian Journal of Biological Education, 6 (2), 243-256. https://doi.org/10.22219/jpbi.v6i2.11456

Primandari, P., Sulasmono, B. S., \& Setyaningtyas, E. (2019). The difference in the effect of the cooperative model type TGT and STAD with cheerful interactive multimedia on social attitudes and cognitive learning outcomes in thematic learning in grade 5 SD. Basicedu's Journal, 3(3), 83-91.

Putri, R. L, Dwiastuti, S., \& Karyanto, P. (2018). The effect of higher-order thinking skills questions in problem-based learning model toward student's critical thinking. Proceeding Biology Education Conference, 15(1), 324-328.

Rumahlatu, D., \& Sangur, K. (2019). The influence of project-based learning strategies on the metacognitive skills, concept understanding, and retention of senior high school students. Journal of Education and Learning, 13(1), 104-110.

Rumahlatu, D., Sangur, K., \& Liline, S. (2020). The effect of complex instruction team product (CITP) learning model on increase student's skills. International Journal of Instruction, 13(1), 587-606. doi: https://doi.org/10.29333/iji.2020.13138a

Said, H., Kasuba, F., \& Sirajudin, N. (2016). Application of learning model student teams education division (STAD) to improve learning outcomes and activities of class VII students on the ecosystem concept at SMP Negeri 6 Bibinoi. Journal of Bioeducation, 4(2), 551-561.

Sambite, F. C, Mujasam, M., Widyaningsih, S., \& Yusuf, I. (2019). Application of project-based learning based on simple teaching aids to increase the HOTS of students. Periodic Scientific Physical Education, 7(2), 141-147.

Samosir, A., Hasruddin., \& Dongoran, H. (2019). Analysis of the quantity and quality of biology teacher and student questions on the excretion system material. Pelita Pendidikan Journal, 7(1), 9-15.

Sanjiwana, P. P. C. M., Pudjawan, K., \& Margunayasa, IG (2015). Analysis of the Social Attitudes of Class V Students on Learning with the 2013 Curriculum. PGSD Journal, Ganesha Education University, PGSD Department, 3(1), 11-18.

Setiawati, H., \& Corebima, A. (2017). Empowering critical thinking skills of the students having different academic abilities in biology learning of Senior High School through PQ4R - TPS Strategy: The International Journal of Social Sciences and Humanities Invention, 4(5), 3521-3526.

Stephani, M. R (2016). The Role of Teachers in Efforts to Increase Higher Order Thinking Through Guided-Discovery Teaching Styles in Physical Education Learning. Journal of Physical Education d 's Sport, 1(2), 34-42.

Sukerta, K., Lasmawan, I. W, \& Natajaya, I. N. (2014). The influence of the cooperative learning model of the stad type on social studies learning achievement with the covariable social attitudes of fifth-grade elementary school students of Cluster III South Kuta District, Badung Regency, Bali. PENDASI: Indonesian Journal of Basic Education, 4(1), 1-11.

Susilowati, I., Iswari, R., \& Sukaesih, S. (2013). The effect of project-based learning on student learning outcomes regarding the human digestive system. Journal of Biology Education, 2(1), 82-90.

Tajudin, Nor'ain, M., \& Chinnappan, M. (2016). The link between higher-order thinking skills, representation, and concepts in enhancing TIMSS tasks. International Journal of Instruction, 9(2), 1-9. 
Wahid, A. H., \& Karimah, R. A. (2018). Integration of higher-order thinking skills (HOTS) with creative problem-solving models. Modeling: Journal of the PGMI Study Program, 5(1), 82-98.

Walfajri, R., \& Harjono, N. (2014). Improved critical thinking skills and thematic learning outcomes of science content through problem-based learning models for grade 5 SD. Basicedu's Journal, 3(1), 16-20.

Widodo, T., \& Kadarwati, S. (2013). Higher-order thinking based on problem-solving to improve learning outcomesoriented to character building students. Education Horizons, 2013(1), 161-171. 